\begin{abstract}
Милош М. Ковачевић ${ }^{*}$ https://doi.org/10.18485/ai_vnia_bora_djordjevic.2018.1.4 Филолошки факултет Београд Филолошко-уметнички факултет Крагујевац
\end{abstract}

\title{
РИМА КАО СТИЛСКА ДОМИНАНТА ПОЕЗИЈЕ БОРЕ ЂОРЂЕВИЋА
}

У раду $^{1}$ се врши анализа риме на основу примјера из четири збирке поезије Боре Ђорђевића, и то првих трију (Равнодушан према плачу, Хеј Словени, и Првих десет година је најтеже) и посљедње објављене Ђорђевићеве збирке (Пусто острво). Рима се анализира с обзиром на њен књижевноумјетнички аспект, прије свега с обзиром на њену улогу у конституисању поетске функције Ђорђевићевих пјесама. Да је рима најсуштаственија карактеристика поезије Боре Ђорђевића најбољи показатељ је чињеница да су од свих пјесама у четирима анализираним збиркама Борине поезије само двије неримоване, као и то да су код Боре Ђорђевића заступљени готово сви родни, квалитативни и дистрибуциони типови рима. Еуфонијска и поетска функција риме у Ђорђевићевој поезији су у двоструко импликативном односу, готово да једна другу подразумијевају, и надопуњавају. Осим тих двију функција рима у поезији Боре Ђорђевића има и текстуалну кохезивну и кохеренцијску улогу, због чега она и представља темељну стилску доминанату.

Кључне ријечи: Бора Ђорђевић, рима, поезија, музика, ритам, еуфонија, поетска функција, род, квалитет и дистрибуција риме

* mkovacevic31@gmail.com

1 Рад је урађен у оквиру пројекта 178014: Динамика структура савременог српског језика, који финансира Министарство просвете, науке и технолошког развоја Републике Србије. 


\section{1. Рима као везивни елемент поезије и музике}

Бора Ђорђевић је кантаутор, што ће рећи умјетник који пише музику и текст пјесама чији је сам извођач. А једна од најбитнијих иманентних карактеристика поезије и музике јесте ритам. Ритам се у поезији, музици и игри као временским, динамичким умјетностима дефинише као „мање или више равномерно понављање неких феномена у релативно краћим интервалима које непосредно доживљавамо, као и уметнички валентна одступања од строге правилности тог понављања" (Ружић 2008: 159). Међу разноврсним језичко-ритмичким сигналима неизоставно се наводи и рима. Рима се обично дефинише као „потпуно или приближно гласовно подударање првенствено на крају два или више стихова, ређе полустихова, које по правилу почиње акцентованим вокалом" (Ружић 2008:155). Рима је, уз то, конститутивни елемент еуфоније као звучног (фоничког, сонорног) састава пјесничког језика, посебно израженог и семантизованог у стиху (Ружић 2008:62). Ако је основна функција пјесничког језика поетска, онда је рима без сумње један од најкарактеристичнијих сигнала (показатеља) те функције, тако да се и преко ње може допријети до суштине поетског у једној пјесми. А поетска функција, у Јакобсонов(ск)ом схватању, проистиче из међуодноса поступака селекције и комбинације језичких јединица, јер „поетска функција пројектује принцип еквивалентности из осе селекције у осу комбинације. Еквивалентност се уздиже до конститутивног начела секвенце” (Јакобсон 1966:296). Рима као подударање завршних гласова стихова или полустихова представља „посебан, згуснут случај ... паралелизма” или еквивалентности (Јакобсон 1966, 310), тако да сама или у комбинацији са другим типовима паралелизама отвара пут ка откривању суштине поетске функције неког пјесничког текста. 


\section{2. Рима у поезији Боре Ђорђевића}

У анализи поезије Боре Ђорђевића риму ћемо испитивати управо с тог њеног књижевноумјетничког аспекта, прије свега с обзиром на њену улогу у конституисању поетске функције Ђорђевићевих пјесама. Бора Ђорђевић је досад објавио десет збирки поезије, с тим да смо овдје у анализу укључили четири Борине збирке поезије - прве три и посљедњу, што ће рећи: 1. Ravnodušan prema plaču (Ђорђевић 1986); 2. Hej Sloveni (Ђорђевић 1987), 3. Prvih deset godina je najteže: sve pesme "Riblje čorbe" i malo više (Ђорђевић 1988), и 4. Пусто острво (Ђорђевић 2017)2.

Анализу риме у поезији Боре Ђорђевића засниваћемо на књижевнотеоријским типовима риме што их доносе рјечници књижевних термина или специјални рјечници рима (в. нпр.: Речник 1992; Чаркић 2001; Ружић 2008). Рјечници су сагласни у томе да постоје три темељна класификациона критеријума риме: 1) критеријум рода, критеријум квалитета и критеријум дистрибуције. Критеријум рода или квантитета заснива се на броју римованих слогова, тако да се све риме дијеле на: једносложне или мушке, двосложне или женске, тросложне или дактилске и вишесложне или хипердактилске риме. По квалитету се риме дијеле на основу степена хомофоније на: праве или правилне, неправе или неправилне, чисте, нечисте и богате риме. Критеријум дистрибуције заснива се на начину размјештања риме у пјесми. А дистрибуција риме може бити разноврсна како на крају тако и унутар стиха, с тим да су најпознатији дистрибутивни типови риме: парна ( $а a ~ b b c c)$, укритена ( $a b a b, c d c d)$, обгрльена ( $a b b a$, $c d d c)$, нагомилана (у више стихова аaаа...); умножена (ако

2 Није без значаја, бар што се Бориног односа према српском језику тиче, ни лако уочљива чињеница да су прве три збирке штампане латиницом, а посљедња ћирилицом. 
ce понавља двапут или трипут: $a a a b c c c b, a b b a a b$ и сл.) (aaabcccb, abbaab), наизмјенична (када се по одређеном принципу смјењују римовани и неримовани стихови), испрекидана (без јасног система римовања) и леонинска рима (римују се крајеви полустихива једног стиха). Иста рима у цијелој пјесми даје монориму (уп. Ружић 2008:158).

Три наведена класификациона критеријума риме род, квалитет и дистрибуција - нису подједнако значајни у анализи риме као стилске доминанте поезије Боре Ђорђевића самим тим што све њихове врсте не карактеришу пјесму као текстостилему, или друкчије речено што се све подврсте појединих типова риме никад не односе на пјесму у цјелини (не само код Боре Ђорђевића, него и наче) него само на поједине стихове или строфе унутар пјесме. То се прије свега односи на неправе или неправилне и нечисте риме које у Бориној поезији никад нису конститутивно начело цјелине пјесме него по правилу само појединих њених дијелова, најчешће појединих стихова.

Рима је стилска доминанта поезије Боре Ђорђевића, доминанта „као средишна компонента уметничког дела: она усмерава, одређује и преображава остале компоненте. Доминанта је та која јамчи за целовитост структуре” (Јакобсон 1978:120). Најбољи показатељ да је рима најсуштаственија карактеристика поезије Боре Ђорђевића јесте чињеница да су од свих пјесама у четирима анализираним збиркама Борине поезије само двије неримоване ${ }^{3}$, и то: 1 . „Не веруј жени која пуши Дрину без

3 У експлицитно неримоване пјесме може се уврстити и еротска пјесма „Народне допуњалке” (1987:38), са апосиопезом, тј. са тачкама на мјесту нереализованих еротемских табуизираних лексема:

Драги драгој хита

дигла му се ...

Чучи Мара на једном камичку

на потоку опрала је ... (1978: 38) 
филтера (остави је)" (1988:39), коју чине четири катрена и два терцета неизосилабичких неримованих стихова, и 2. „Успаванка” (1988:156), састављена од три катрена, са неримованим, неизосилабичним стиховима.

\section{1. Родно хоморимне пјесме}

У поезији Боре Ђорђевића нису подједнако чести ни обични на нивоу пјесме као текстостилеме, дакле као карактеристика пјесме у цјелини, сви родни типови риме. Друкчије речено, нису подједнако карактеристични типови свих РОДНО ХОМОРИМНИХ ПЈЕСАМА. Чини се да су најрјеђе, чему се није ни чудити, пјесме са једносложном или мушком римом, и пјесме са вишесложном или хипердактилском римом.

Досљедно проведену мушку риму има једино пјесма „Пролазност живота I” (из збирке Hej Sloveni, 1987: 39): пјесму чине четири катрена с мушким затвореним римама: 1. строфа: сис-вис; сис-бис; 2. строфа: груд-луд;

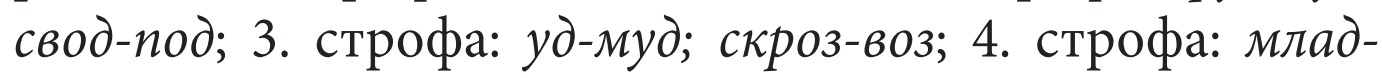
pad; mad-nad.

Ни у једној Бориној пјесми из анализираних збирки готово да нема досљедно проведене вишесложне (најмање четворосложне) хипердактилске риме. Томе је најближа астрофична четворостишна, са двије нечисте хипердактилске риме (магараца-папараца; магарчину-шамарчину) пјесма „Папараци”" (2017:166).

Та, хипердактилска рима је, међутим, апсолутно већинска у пјесми „Снаге опозиције” (1988:84-85), која је састављена од девет строфа, и то осам катрена и завршног дистиха; има дакле 34 стиха, од којих је чак 26 сти-

4 Град је препун магараца

Такозваних папараца.

Где год видиш магарчину

Припали му шамарчину. 
хова увезано хипердактилском римом (опозиције-позииије; композииије-пропозиције // резолуције-револуиије; институиије-егзекуиије итд., а само у осам стихова остварена је дактилска рима (инјекиије-лекиије; рације-стабилизације; нација-доминација; зајебаниије-санкиије), с тим да су све строфе још и хомојотелеутонски повезане, јер се сваки од стихова строфе завршава истом вишефонемском групом гласова која није нужно подударна са групом гласова што улазе у риму: 1. строфа: -nозиuије, 2.: -уције, 3.: -екиије, 4.: -ације; 5.: -ација; 6. -ениије; 7.: -иција; 8.: -ација, и 9. строфа: -анција. Иако је само једна пјесма у цјелини римована хипердактилском римом, овај тип риме врло је обичан у строфама појединих Бориних пјесама. Хипердактилска рима се тако код Боре Ђорђеввића чешће сусреће као строфична него као текстемска (текстостилемска) рима, као нпр. у пјесми „Врло, врло задовољан тип” (1988:26-27), гдје је друга шестостишна строфа (секстина) готово сва у хипердактилској рими.

За разлику од хипердактилске риме, дактилска (тросложна) рима обична је, мада не и много честа, као структурно текстостилемско начело пјесама Боре Ђорђевића. Наводимо само неколико пјесама за потврду: 1. „Нећу да те волим” (1988:82) - пјесма од три катрена с досљедном дактилском римом, сем насловног четири пута поновљеног рефрена; 2. „Кад је било орално...” (1987:37), пјесма коју чине октава и дистих, с досљедно реализованом дактилском римом, с тим да риму у октави „подржава” хомојотелеутонски завршетак-но; 3. „Колеге” (1987:105), астрофична десетостишна пјесма с парном дактилском римом; 4. „Компромис” (1986: 75), пјесма састављена од двије неизосилабичне строфе: дистиха и дециме, са досљедно реализованом парном дактилском римом, с тим да су сви стихови дециме хомојоптотонски структурисани: завршавају се истим императивним 
наставком -ите; 5. „Јеванђеље по Матији”5 (1987:59), асторфична, једанаестостишна неизосилабична пјесма с дактилском римом, итд.

Од свих родно хоморимних пјесама у поезији Боре Ђорђевића неупоредиво су најбројније оне са двосложном или женском римом. Њих је вјероватно више него заједно свих других родно хоморимних пјесама. Зато овдје помињемо само неке: 1. „Права истина о хватању Драже Михаиловића" (1987:111) - астрофична, деветостишна, с досљедно проведеном парном женском римом; 2. „Самокритичка песма” (1987: 94) - астрофична, четворостишна, парна женска рима; 3. „Хлеба и игара” (1988: 83) - пет катрена, сви римовани женском римом; 4. „Киша пада у Зиданом Мосту” (1988:149), „Грешник под небеском капом” (1988:152), „Црвена су дугмад притиснута" (1987:75) - све три четворокатренске са женском римом; 5. „Песма са поруком” (2017:50-51) - пјесма од шест катрена, с досљедно реализованом женском римом, и многе многе друге Борине пјесме.

\subsection{1. Родно хетероримне пјесме}

Од родно хоморимних код Боре Ђорђевића су неупоредиво чешће родно хетероримне пјесме, тј. пјесме у којима се мијешају различити родни типови риме.

5 Одувек сам гајио симпатије спроћу Матије и његове братије. Па ипак Бећковић није неки срећковић.

Није он члан Академије због физике и хемије. За мене Матија значи демократија, он своју истину тера на чистину. 
Навешћемо за потврду само неколико: 1. „Нови светски поредак" (2017:30-31), пјесма од осам катрена, са двапут реализованим рефренским катреном; у пјесми интерферирају сви родни типови риме: мушка (мрак-поредак; побачај-крај), женска (казна-празна, било-кило и др.), дактилска (цркава-смркава; једнообразна-безобразна), и хипердактилска рима (сахрањени-забрањени; исписани-избрисани; укинути-угинути); 2. „Спонзори” (2017:35-37), састављена од девет катрена и завршног дистиха; рима мјешовита - од мушке до дактилске; 3. „Равнодушан према плачу” (1986:112-113) - четворострофна: три дециме, и катрен као трећа строфа - комбинација дактилске (пакао-плакао; ловоре-говоре и сл.), женске (зине-врлине; чешће-жешће, вицу-лицу; спровод-повод) и мушке риме (сам-шљам); 4. „Диско мишић” (1988:89) - шест катрена, комбинована родна рима мушка: сав 6. катрен; женска: сав пети катрен и дактилска рима (у другом катрену: ручају-случају), први, трећи и четврти катрен (пар мушке, пар женске риме); и многе друге пјесме; 5. „Прошлости (ниси била богзна шта)” (1988:128) - четири строфе, прве три катрени, посљедња дистих: Прошлости, /молим те, опрости; прва и друга строфа укрштена рима: 1. и 3. стих прве дактилска: увреда-уједа, а друге - хипердактилска: задужио-заслужио; а 2. и 4. стих - мушка, једносложна: смеј-кеј; слон-он; трећа строфа парна рима - 1. и 2. стих мушка (шта-ја) а 3. и 4. женска, двосложна, и на крају дистих с парном нечистом дактилском римом; 6. „Када падне ноћ” (1987:72) - пет неизосилабичних строфа, прве три катрени, посљедње двије терцети: 1. и 2. строфа - дактилска наизмјенична (полустрофична) рима јер се римују само други и четврти стих: возови-лозови; обично-одлично; трећа строфа укрштена мушка рима: пробисвет-свет; стид-зид; 4. и 5. строфа терцети, прва два стиха римована мушком парном римом: ноћ-упомоћ; дан-досадан, трећи, рефренски 
се не римује: јер тебе нема ту; 7. „Гадови” (1987: 107) двострофична пјесма: октава и дистих; у октави дактилска, женска и мушка рима, у дистиху женска.

\section{2. Дистрибуционо хоморимне пјесме}

Од родно хоморимних пјесама за поетску функцију су битније дистрибуиионо хоморимне пјесме Боре Ђорђевића. Будући да дистрибуција подразумијева распоред рима унутар пјесме, она на готово очигледан начин упућује на кохезивну и кохеренцијску функцију риме. Друкчије речено, дистрибуцијски типови риме представљају не само композиционо него и смисаоно начело пјесме у цјелини. Код Боре Ђорђевића сусрећу се различити (под) типови дистрибутивно хоморимних пјесама, и још различитији дистрибутивно хетероримних пјесама.

\subsection{1. Пјесме с парном римом}

Готово све двостишне, тростишне или катренске Борине „реминисценцијске”, односно „рефлексивне пјесме” парно су римоване: 1. „Хеј, Словени! (Предлог за химну)” (1987: 5): Хеј, Словени и остали / дебело смо заостали; 2. „Песма моје жене приликом поласка на посао у преподневну смену" (1987: 54): Да ли да устанем / или да одустанем?; 3. „Црногорска народна молитва" (1987: 19): Хеј, господе са небеса, / звизни два-три земљотреса; 4. „Најглупљи стих на свету” (1987: 35): Нема струје / због олује. / Упали шибицу / да ти видим рибииу. Итд.

И мимо кратких „реминисценцијских” пјесама Бора Ђорђевић врло често (па зато и наводимо већи број потврда) у дужим астрофичним, хомострофичним и хетерострофичним пјесмама употребљава само парну риму, као нпр. у пјесмама: 1. „Скупио сам ђутуре... ”) (1987: 24) - састављеној од два катрена и завршног дистиха, са 
седмерачким стиховима парно римованим; 2. „Могу да повећам брљу и пиво..” (1987: 26) - астрофична пјесма од осам неизосилабичких парно римованих стихова, 3. „Крокодилска љубав” (1987:56) - коју чини седам дистишних строфа са десетерачким парно римованим стиховима; 4. „Разјебани архипелаг” (1987: 36) - шест катренских строфа са неизосилабичним парно римованим стиховима, 5. „Партизани” (1987: 113) - пјесма од пет дистишних строфа, сваки парни стих завршава се ријечју „партизани”, с којом се римује ријеч из непарног стиха (грани; страни; брани; дани; храни); 6. „Позајмила је паре, полудела је скроз, купила је карту и села је у воз" (1988:14) - пјесма од три хетеросилабична катрена с парном римом; 7. „Јужна Африка '85 (Ја ћу да певам)” (1988:96) - пјесма од пет парно римованих седмерачких катрена, 8. „Љути рок-ен-рол” (1988:99) - два катрена и дистих, неизосилабични стихови, с парном римом; 9. „Гадови” 1987:107) - двије строфе, октава и дистих, рима досљедно парна; 10. „Закашњење на тезгу” (1987:98) - четири парно римована дистиха; „Ластово” (1987:22) - четири катрена и завршни дистих с досљедно парном римом; 11. „Скупио сам Ђутуре..." (1987:24) - два катрена и завршни дистих, с парном римом; 12. „Леси се враћа кући” (1987:68) - четири катрена, рима досљедно парна; 13. „Пусто острво” (2017:79) - 12 строфа: један терцет, и дистих, десет катрена, све с парном римом; 14. „Мобилни” (2017: 13) - пјесма од три катрена и трипут поновљеног рефренског дистиха, с досљедно проведеном парном римом; 15. „Плајваз” (2017:16-19) - пјесма од дванаест строфа: осам катрена и једне четири пута поновљене октаве, с досљедно парном римом; 16. „Спонзори” (2017: 35-37) - девет катрена и завршни дистих, све парна рима; 17. „Помало тужно” (2017:42-43) - шест катрена с парном римом; 18. „Песма са поруком" (2017:50-51) - шест парно римованих катрена; 19. „Вратиће се роде” (2017:106-107) - осам парно римо- 
ваних строфа: шест катрена и једна поновљена секстина; 19. „Батина је из раја изашла” (2017:108-109) - пет парно римованих катрена; 20. „Батина је из пакла изашла” (2017:110) - три парно римована катрена; 21. „Кинеске наочаре” (2017: 122) - астрофична, 36 стихова, сви парно римовани; 22. „Граница” (2017:127-128) - шест катрена с парном римом, итд. итд.

Парна рима је, без сумње, уз наизмјеничну, најфреквентнији дистрибуциони тип риме у Ђорђевићевој поезији, и то не случајно, јер је она и најбоља подлога музичке еуфоније, тј. еквивалентности поетске и музичке функције риме. Осим тога, њој је подједнако подобна готово свака структура строфе с парним бројем стихова од дистиха до дванаестерца, па чак и у случајевима када строфу не чини парни број стихова, јер парна рима омогућава међустрофично римовање (као нпр. између два терцета).

\subsection{2. Пјесме с укритеном римом}

Врло често, мада неупоредиво рјеђе него на парној, хоморимност Бора Ђорђевић темељи на укрштеној рими, као нпр. у пјесмама: 1. „Леси се враћа кући” (1987: 68) - пјесма од четири десетерачка катрена с укрштеним римама; 2. „Склоните те старце” (1986: 14) - четири дванаестерачка катрена с укрштеном римом; 3. „Џукеле ће ме докусурити" (1988:69) - пјесма од шест катренских неизосилабичких строфа, понављају се трећа и шеста као рефренске, све строфе имају укрштену риму, с тим да је у рефренској строфи укрштана лексичка рима, која је истовремено и нагомилана нелексичка $-y \kappa(\pi) е л e^{6}$

6 Мене су бабе врачаре уклеле, да ми о глави раде џукеле.

Мене су бабе врачаре уклеле, прогоне ме џукеле. 
(уклеле-иукеле-уклеле-иукеле); 4. „Говноваљ” (2017:1415); 5. „Овде” (2017:20-21); 6. „Ко о чему” (2017:24-25); 7. „Кад неко љубав урекне” (2017:79-80) - све четири (4-7) састављене од по шест катрена с укрштеном римом; 8 . „Нови светски поредак” (2017:30-31) - осам катрена с укрштеном римом, с тим да је један рефренски, двапут поновљен; 9. „Пад” (2017:63-64) - пет катрена с укрштеном римом; 10. „Ужасно ми недостаје” (2017:73) - четири катрена с укрштеном римом, с тим да се сваки катрен завршава римованим насловним рефреном; 11. „Плашим ce” (1986:79); 12. „Rock'n’roll za kućni savet” (1988:11) - oбje састављене од по пет катрена с укршетном римом. Итд.

Као што се из наведених примјера види, укрштена рима код Боре Ђорђевића исључиво се јавља у пјесмама састављеним од катрена, јер је катрен као четворостих идеална пјесничка структура за укрштену риму.

\subsection{3. Пјесме са наизмјеничном римом}

Од свих типова хоморимних пјесама код Боре Ђорђевића примат имају пјесме са наизмјеничном римом, тј. римом „која се остварује током целе песме у наизменичном смењивању с неримом" (Чаркић 2001: 114). Ријеч је о својеврсној полустрофичној рими, која у комбинацији са неримованим стиховима може бити или укрштена или парна. Такву риму имају десетине Бориних пјесма, јер је она очито врло захвална за музичко извођење пјесме, пошто су у саодносу с неримованим врло наглашени римовани стихови, тако да на фону различитости римована сличност добија већу пјесничко-музичку вриједност. Навешћемо нешто већи број наслова Бориних пјесама с наизмјеничном римом, с тим да се ни оне не могу сматрати чак ни већинским дијелом: 1. „Балада о пензионеру" (1986:38) - четворокатренска пјесма с наизмјеничном укрштеном римом парних стихова (што ће рећи 
да су римовани парни, а неримовани непарни стихови); 2. „Одлазим на боловање” (1986:39); 3. „Дежурна песма” (1986:41) - обје пјесме од по пет катрена с наизмјеничном укрштеном римом парних стихова; 4. „Крај” (1986:43) - пјесма од пет катрена с наизмјеничном укрштеном римом парних стихова у прве двије и посљедње двије строфе, а с наизмјеничном укрштеном римом непарних стихова у трећој, средишњој строфи; 5. „Преко Новог Београда..." (1986:76) - три катрена с наизмјеничном укрштеном римом парних стихова; 6. „Погледај дом свој, анђеле” (1986:83) - пјесма од пет квинти, тј. петостишних строфа, с тим да се римују само два сусједна стиха у свакој од строфа, и то у првој, другој, трећој и петој 3. и 4. стих (потресне-болесне; гомили-поломили; амове-храмове; освете-осете) а само у четвртој строфи 2. и 3. стих (ратова-вратова); у питању је, дакле, досљедно проведена наизмјенична парна рима; 7. „Рано јутро” (1986: 10) - трокатренска десетерачка пјесма, у свим катренима римују се само парни стихови: други и четврти (нuје-nuje; мозак-Козак; зида-стида); 8. „Дежурна песма” (1986: 41) - пјесма од пет катрена, с тим да се сваки четврти стих, а самим тим и строфа завршава лексемом „град”, с којом се римује лексема с краја другог стиха (хлад; склад; млад; nад, u гад), док неримовани остају први и трећи стих; 9. „Рекла је” (1988: 33) - пјесма од пет катрена, сви с дјелимичном римом, досљедно римовани други и четврти стих сваког катрена; 10. „Ноћас би' тако иш'о у штету” (1986: 60) - три петостишне строфе (квинте) с неизометричним стиховима, с тим да је четврти стих у свакој строфи насловни (ноћас би' тако ищ'о у штету) а пети стих узвик Joj! Римовање у свакој строфи обухвата само парне стихове, други и четврти, с тим да се у свакој строфи, будући да је у њима четврти стих исти, римује завршна ријеч другог стиха са ријечју „штету” (цигарету; у лету; мету); 11. „Звезда поткровља и сутерена” (1988:12) - четири 
катрена с наизмјеничним римама у парним стиховима; 12. „Ја сам још она иста будала” (1988:15) - пјесма од пет строфа: три терцета на почетку с неримованим првим стихом, и два катрена на крају с наизмјеничном римом парних стихова; 13. „Превара” (1988:41) - три катрена с наизмјеничном укрштеном римом парних стихова; 14. „Мирно спавај” (1988:18) - сонет, неизосилабични стихови; у катренима римовани унутрашњи стихови (други и трећи), у терцетима парна рима првог и другог стиха; 15. „Хајде, сестро слатка” (1988:29) - четири катрена с наизмјеничним римама у парним стиховима; 16. „Добра земљо, лажу” (2017:104-105) - шест катрена с наизмјеничном римом у парним стиховима. Итд.

\subsection{4. Пјесме с леонинском римом}

Интересантно је да се ни у једној од пјесама Боре Ђорђевића у четири анализиране збирке хоморимност не остварује обгрљеном римом. Обгрљена рима код Боре Ђорђевића је строфична а не текстостилемска карактеристика. Обгрљена рима очигледно није као нпр. наизмјенична, парна или укрштена погодна за музичку хомофонију. Обгрљена рима прије је карактеристика писане неголи пјеване поезије, прије је поетска неголи музичка карактеристика. Али се зато у појединачним пјесмама Боре Ђорђевића хоморимност остварује на специфичан начин, као на примјер у пјесми „Зашто куче арлауче" (1987: 51), састављеној од четири терцета, с репом, тј. са завршним „строфичним” стихом, у коме је једино садржана насловна, удвојена или крунисана рима (...куче арлауче), док је у свим осталим стиховима реализована леонинска рима, с тим да први и трећи стих првог и другог терцета имају и медијалну риму; сви стихови су осмерачки, само је посљедњи каталектичан (једанаестерац); дакле, леононска рима досљедно је реализована сем 
у посљедњем стиху, гдје се остварује крунисана, удвојена рима, која га повезује с насловом: куче арлауче. Узме ли се у обзир и наслов, пјесма има прстенасту композицију.

\subsection{5. Моноримне пјесме}

Поједине краће Борине пјесме су моноримне, као нпр. астрофична тростишна „Песма о МЗ Србији” (1986: 90): Наталитет опада, / па Србија пропада, / то ми се не допада; или пак четворостишна „Песма о МЗ Србији II” (1987: 19): Играле се делије / на сред земље Србије, / a онда су делије / стрпали у ћелије.

\subsection{6. Пјесме са строфичном моноримом}

У једној јединој пјесми хоморимност се заснива на тројној стробичној рими, и то у пјесми „Нисам знао да сам зао” (2017:98), састављеној од пет терцета, с тим да је сваки стих терцета „монориман”, односно с нагомиланом римом, која подразумијева понављање исте гласовне секвенце у свим стиховима строфе (знао-зао-упознао // радознао-звао-зао // слажу-кажу-мажу // дају-крају-знају // ждрао-жао-зао); али се, као што се види, успоставља и међустрофична рима између посљедњег стиха прве и првог стиха друге строфе (упознао-радознао), тако да су први, други и посљедњи терцет моноримни!

\subsection{7. Дистрибуиионо хетероримне пјесме}

Највећи број пјесама Боре Ђорђевића има мјешовиту дистрибуциону риму. У питању су, дакле, дистрибуционо хетероримне пјесме. С обзиром на то колико је нехоморимних строфа унутар пјесме, све дистрибуционо хетероримне пјесме Боре Ђорђевића могу се подијелити у двије велике скупине: 1) пјесме с једном диференцијал- 
ном римованом строфом, и 2) пјесме с интерференцијом различитих дистрибуционих типова рима у више строфа.

\subsubsection{1. Пјесме с једном нехоморимном строфом}

Велики је број пјесама у којима само једна строфа „ремети” хоморимност, тј. пјесама у којима се само једна строфа по типу риме разликује од свих других. Разлоге томе није тешко докучити. У питању су по правилу строфе које представљају структурна и/или смисаона тежишта саме пјесме: најчешће или прва као отварачка строфа, или посљедња као затварачка. Између великог броја таквих пјесама у анализираним збиркама Боре Ђорђевића овдје ћемо поменути само сљедеће: 1. „Мексиканска песма" (1986: 22) - пјесма састављена од пет катрена с наизмјеничном римом у парним стиховима (другом и четвртом) прва четири катрена (месту-фиесту; мрачно-тачно; ранча-Панча, право-Бртаво), док пети катрен има укрштену риму, и гласи: Дона Розита, немој да скачеш,/ таласи реке врло су влажни,/ обриши сузе, немој да плачеш,/ у овом филму меци су лажни.; 2. „На оном отоку (острву) неки су отекли а неки су се острвили" (1987: 109) - пјесма састављена од два катрена с укрштеном римом и завршног дистиха с парном; 3. „Три ливаде нигде нема 'лада волео сам девојку из града” (1986: 13) - четворокатренска пјесма, изосилабична, десетерачка, центонска, јер су за четврти стих у прве три строфе узети стихови из фолк-музике: чаше томим руке ми крваве; Мујо кује кона по мјесеиу; од извора воде 2 nутића; само у завршној строфи нема центона, него је стих 12-стерац (заклағаш ми сунце, сиђи са мог неба), што је, уз риму, друго изневјерење, јер је рима у првој, трећој и четвртој строфи укрштена, а у другој наизмјенична, полустрофна (Лочу свињски очеви и мајке / што рађају кретенасту децу / мани сада тупаво потомство / Мујо кује коња по мјесецу); 4. „Много тога вуца- 
рам са собом" (1986: 29) - пјесма од пет катрена, у прва четири катрена досљедно проведена укрштена рима, а у посљедњем катрену парна; 5. „Није ми ништа” (1986: 42) - пјесма од четири катрена, прва три с наизмјеничном римом у парним стиховима; пата строфа с укрштеном римом. Итд. Таквих хетероримних пјесама, с једном по рими разликовном строфом, у збирци Првих десет година је најтеже ... (1988) има чак осамнаест $(17,20,23$, $24,25,27,28,31,32,37,46,51,75,83,97,110,148,157)$, док их у збирци Пусто острво (2017) има пет (22, 28, 40, 46 и 77). Нехоморимна строфа у оваквим пјесмама показује да је пјесник Бора Ђорђевић свјесно избјегавао композиционо начело структурне строфичне „немонотоније”. Друкчије речено, нехоморимна строфа на својевеврстан начин има композицоно затварачку улогу, и то прије на кохеренцијском неголи на кохезивном плану, што ће рећи да је напуштање хоморимности задато прије свега семантичком структуром пјесме.

\subsubsection{2. Пјесме с више нехоморимних строфа}

У великом броју пјесама хетероримност се остварује између више од двије строфе, тј. рима захвата већи обим од једне строфе у пјесми. Таква хетероримност може бити остварена и у астрофичним пјесмама, за што су најбољи примјери шестостишна пјесма „Ко то каже...” (1987:17), у којој су први и други стих римовани парном римом, док је преосталих шест стихова римовано обгрљеном римом: Ко то каже / ко то лаже/ Србија је мала? / Тај се, куме, / не разуме, / обична будала. Слична је структура риме и у пјесми „Кит, ајкула и слон” (2017:111) - астрофичној пјесми од 12 стихова, од којих су прва два парно римовани, сљедећа четири су са обгрљеном римом, наредна два (седми и осми) имају парну риму, а посљедња четири римовани су обгрљеном римом: Кит ајкула / Кад је чула / Слона да се хвали, / С правом она / Грди слона, / Каже, 
ћути, мали. / Ем си мағи, / Ем си тағьи, / Не можеш ми прићu, / Боље расти / Патуљасти, / Можда ћеш ме стићи.

У оквиру вишестрофних хетероримних пјесама интерферирају различити дистрибуциони типови рима, као нпр. у пјесми 1. „Сибир” (1987: 83), која је трострофна пјесма састављена од катрена, терцета и дистиха; катрен је са еквивокном римом, терцет са триплетном нагомиланом римом, а завршни дистих с парном римом; 2. „Манијаци крстаре по граду” (1986: 23) - пјесма од шест неизострофичних строфа: прве двије и посљедње двије су катрени, унутрашње двије терцети; прве три строфе (два катрена и терцет) различито су римоване: прва има парна, друга укрштену, треће тројну нагомилану риму (квачило-откачило-смрачило), посљедње двије имају нечисту укрштену риму, док је четврта строфа неримована гола" (1987: 73) - петострофна пјесма с неизосилабичним стиховима, четири прве строфе су катрени, завршна терцет; рима у првој и трећој строфи наизмјенична у парним стиховима; у другој строфи парна; у четвртој укрштена (животу-сачувала-срамоту-одувала); у терцету парна, са завршним неримованим стихом: Не спавај гола / чак ни до пола / јер то је опасно по живот; 4. „Како је лепо бити

7 Људи у Сибиру брину се да преживе велике минусе.

Самоубице скину се па изађу на минусе.

Тамо има

љута зима, таква клима.

Људе шаљу у Сибире по могућству да се смире.

8 Пешаци су досадни, пешаци су спори зато их обори. 
глуп” (1988: 59-60) - шестокатренска осмерачка пјесма: први, други, пети и шести катрен имају прстенасту композицију јер су почетни и завршни стих насловни, а унутар њих два стиха иду с парном римом, тако да је у ствари у тим строфама реализована специфична обгрљена рима; трећа и четврта строфа немају у свом саставу насловни стих, али имају укрштену риму; 5. „Немој срећо, немој данас” (1988: 24) - пјесма од четири строфе, прве три секстине, у првом стиху сваке од строфа реализује се леонинска рима (Дан је тмуран, ја мамуран; Ти си крива због мог пива; Боље спречи ружне речи); други стих насловни, рефрен, неримован, а преостала четири с парном римом. У завршном катрену нема леонинске риме, а рефренски стих је на крају, и римује се са претпосљедњим, тако да се остварује парна рима:

Ми смо, ето, близу краја, један корак до очаја, чувај мало наде за нас, немој, срећо, немој данас.

Интерференција рима условљена је прије свега улогом риме у остварењу специфичне поетске функције пјесме у цјелини. Јер „премда се рима по дефиницији темељи на редовном поврату еквивалентних фонема или фонемских група, њено третирање искључиво са становишта звука представљало би нездраво упрошћавање. Рима нужно укључује семантички однос између римованих јединица" (Јакобсон 1966:309) У рими, рећи ће Јакобсон позивајући се на енглеског пјесника Хопкинса, „постоје два елемента лепоте коју рима дарује духу: сличност или истоветност звука и несличност или различитост значења". Какав год био однос између звука и значења у различитим техникама риме, обе сфере су нужно захваћене (Јакобсон 1966:309-310). 
Кратко речено, еквивалентност звука, пројектована у секвенцу као њен конститутивни принцип, неминовно укључује семантичку еквивалентност, и на сваком језичком нивоу свака конституента такве једне секвенце изазива један од два корелативна доживљаја које Хопкинс згодно дефинише као „упоређивање ради сличности” и „упоређивање ради несличности” (Јакобсон 1966:310311). Из тога проистиче, да „амбигуитет представља неотуђиву унутрашњу одлику сваке поруке усредсређене на саму себе, укратко - пратећу карактеристику поезије” (Јакобсон 1966:313). Показаћемо то на једној врло познатој пјесми Боре Ђорђевића, на пјесми „Правила, правила" (1988:57), састављеној од шест строфа, од којих је прва терцет, друга катрен, трећа децима (десетостих), четврта катрен, пета октава (осмостих), и шеста, завршна катрен. Трећа и четврта строфична цјелина тешко се, међутим, могу сматрати правим строфама, оне су прије строфоиди ${ }^{9}$ него строфе: у њима се нижу општеприсутне опомене и забране, стихови су идиоматизовани неизометрички изрази с директивним (најчешће заповиједним) значењем, са по једном случајном леонинском римом, и то у шестом „стиху” првог строфоида (Попуни формуларе, ако хоћеш паре), и петом стиху другог строфоида (Част свакоме, вересија никоме!). Зато је боље рећи да пјесму „Правила, правила” чине четири строфе и два строфоида. (Не)рима хармонизује звучну и смисаону

9 „Постоје два прелазна ступња између строфичне организације песме и стихичког низања стихова: строфоиди и одсечци. Строфоид само личи на строфу. То је група стихова не већа од претпостављеног обима најдуже строфе (по једнима то је 10, по другима до 14 стихова), који се неједнако нижу у песми. Одсечци су дужи низови (више од 14) стихова који су графички издвојени (подсећају на параграфе у прозном тексту). У поезији није ретка појава мешања строфе са строфоидима, одсечцима или астрофичним низом стихова" (Грдинић 2007:21-22). 
компоненту пјесме. То значи да је и карактеристична употреба и неупотреба риме усаглашена са смисаоном структуром пјесме, или боље речено: у фунцији смисаоног значења пјесме. Прва терцетна строфа је презасићена типовима риме, и гласи:

Правила, правила, да би ме удавила, или кичму савила и скроз ошашавила, нека глупа правила, у црно ме завила.

Као што се види, седам лексема повезује иста нагомилана дактилска рима, или строфична монорима -авила. Та подударана гласовна секвенца (-авила) терцет премрежава разнотипским римама: 1. леонинском унутар сваког од трију стихова (правила-удавила; савила-ошашавила; правила-завила), 2. тројном медијалном на границама сваког од полустихова (правила-савила-правила), и 3. тројном нагомиланом на крају стихова (удавила-ошашавила-завила). И ту није крај, унутар првог полустиха остварује се контактна лексичка рима (правила, правила), а између првог и другог, и другог и трећег стиха остварује се анексна (епимезофорска) рима, јер се римује крај претходног (првог и другог) стиха са крајем наредног (другог и трећег) полустиха (удавила-савила; ошашавила-правила). Строфа од три стиха тако је кохезивно увезана са пет типова риме: леонинском, медијалном, завршном (епифорском), контактном и анексном (епимезофорском). Као да је пјеснику био циљ да на примјеру риме покаже опште постојање правила, и то преко пјесничких, разнотипских правила римовања, што на најбољи начин отјеловљују принцип еквивалентности као основни принцип поетске функције језика.

Прва строфа на композиционом плану готово да унутар пјесме има инхотаивну, отварачку функцију. Она представља говор о правилима уз њихову потврду 
са пет различитих типова риме, чија реализација захтијева поштовање строгих теоријских принципа. У другој строфи као да пјесник с теоријско-расправљачког прелази на прагматички дискурс правила, на њихово премјештање из теорије у праксу, на њихову примјену и/ или конкретизацију:

Хало! Јел' чујеш? Немој да псујеш,

Немој да пљујеш по поду!

Кад околину загађујеш и трујеш, обавезно повуци воду!

И ова је строфа попут прве презасићена римама. Али су те риме сасвим друкчије дистрибуиране, што је и логично с обзиром на то да је прва строфа терцет, а ова друга катрен. Оно што на плану риме повезује ове двије строфе јесте леонинска и анексна рима, с тим да леонинска рима није реализована у свим стиховима, него само у непарним, у првом и трећем (чујеш-псујеш; загађујеш-трујеш). На границама полустихова првог и другог стиха реализована је мезорима (чујеш-пљујеш), док је између краја првог стиха и краја другог полустиха остварена анексна (епимезофорична) рима (псујешпљујеш). Леонинска рима изостаје у парним стиховима. На нивоу катренске строфе рима је укрштена (псујеш-поду-трујеш-воду). Модификације у реализацији дистрибуционих типова риме у односу на прву терцетску строфу прије свега су за семантику саме строфе. Наиме, строфу чине стихови који имају вриједност реченииа са yопштеноличним значенем, а оне „означавају глаголску радњу која је појединачна, али се транспонује на општељудски и општевременски план, тако да се може односити на човека уопште и на свако лице" (Маројевић 2000:237), с тим да код Боре Ђорђевића те реченице, како што се види, имају презентски предикат у другом лицу једнине. 
Употреба другог лица омогућава потискивање индивидуалног пјесниковог зарад општег, за које пјесник сагласност налази код замишљеног читаоца као саговорника. Уопштониличне реченице тако омогућавају да пјесник своја искуства са директивним правилима подијели као општа са читаоцима, или пак да читаоци за своја искуства нађу сагласност код самог пјесника. А да истовремено правила своју потврду не налазе само код читалаца него и у поетској структури строфе, прије свега у типовима еквивалентности који проистичу из садејстава различитих дистрибуционих типова рима.

У трећој строфичној цјелини, десетостишном строфоиду, сви стихови су експламативни, сваки се завршава ускличником, и сваки изражава у виду правила одређено упозорење или заповијест као забрању чињења онога што се реченицом-стихом изражава:

Незапосленима строго забрањен приступ на градилиште! Кажњиво је пушење у кретању!

Не говори у строју, мајмуне!

Забрањено за младеж испод 18 година!

Не паркирај - истовар угља!

Попуни формуларе, ако хоћеш паре!

Забрањен разговор са возачем!

Чувај се, пас уједа!

Проверено - мин њет!

Мирно!!!

Сви стихови су дати у форми или неодређеноличних или уопштеноличних реченица. Изражавају општа правила понашања везана за одређене ситуације. Та правила, међутим, као да не налазе свој одраз у поетском језику. Посматрана из перспективе риме као основне кохезивно-кохеренцијске доминанте поезије Боре Ђорђевића, дата правила не добијају потврду у поетској истини. Она 
су насупротна поетској функцији заснованој на принципу еквиваленције у чијој је подлози рима. Иако изостаје на рими заснована еквиваленција, исказе што чине овај строфоид ипак повезује перинцип еквиваленције, јер без тога они не би могли добити статус поетских исказа. Сви стихови су, наиме, еквивалентни с обзиром на екскламативни комуникативни тип исказа, који је чак градацијски степенован, будући да се посљедњи стих „Мирно!!!” завршава троузвичником, што је лексичко-интонациони показатељ субјектове немогућности да се одупре правилима, тј. потпуног субјектовог повиновања правилима, односно онима што та правила прописују.

У четвртој строфи зато се пјесник враћа личним правилима, правилима личног љубавног искуства, и одмах се успоставља хармонијски саоднос између стварносне и поетске истине, чији су структурни показатељ еквиваленције засноване на римама:

Правила постоје кад се двоје воле, Мама ти је рекла: Не дај прве ноћи. Може до појаса, не дирај ме доле, - А те друге ноћu, можда нећу моћи.

Четврта је строфа, попут друге, катренска, с различитим дистрибутивним типовима риме. Сва четири стиха обједињена су укрштеном женском римом (воленоћu-доле-моћu). Први и четврти стих еквивалентни су с обзиром на то да је у њима остварена леонинска рима (постоје-воле; ноћu-моћu), истина у првом стиху нечиста, али је зато подржава чиста рима завршне лексеме полустиха са претпосљедњом лексемом првога стиха (постоје-двоје). И уза све то, први се стих завршава нечистом удвојеном или крунисаном римом (двоје воле). У овој строфи више нема уопштеноличног нити неодређеноличног значења - у првом је плану лично искуство с 
љубавним „правилима”. А да је у питању конкретизација правила, најбоље се види по томе што су чак три стиха (други, трећи и четврти) дата у форми управног говора, с тим да су два исказа управног говора пјесникова, а само један (трећи), дат као слободни управни говор, представља говор његове љубави као саговорнице. Управни говор у другом стиху само је по форми управни, али је значењски заправо неуправни говор, јер представља пјесникову репродукцију замишљеног мајчиног говора кћерци. Наглашено лично искуство с љубавним правилом „прве ноћи с вољеном" потврђује и лична (а не уопштено или неодређенолична) употреби личних глаголских облика (не дирај; нећу моћи). Ни правила „двоје који се воле” као да не могу бити ослобођена проблема, као да је свако правило насупрот слободе. Као да нас на сваком кораку чека и опомиње неко од (бе)смислених правила. То пјесник посебно наглашава све самим екскламативним стиховима наредног осмерачког строфоида:

Свака намерно разбијена чаша се плаћа!

Не служимо пијане госте!

Забрањено хранити животиње!

Кажњиво је играње руком у шеснаестерцу!

Част свакоме, вересија никоме!

У овој просторији се не пуши!

Проверено мин њет!

Мирно!!!

У подлози свих стихова стоје безличне или пасивне реченице, без обзира на то да ли је у питању синтаксички или семантички пасив. Нема ниједне личне реченице, чак ни оне уопштеноличне. У питању су, дакле, стихови-реченице чија се радња не приписује активном личном субјекту. Стиховима се изражавају различита правила која говоре о забранама и „препорукама”, у свима 
њима субјекат је „трпилац”, што се најбоље види по посљедњем стиху који, показује то и троструки узвичник, представља оштру команду (Мирно!!!), која готово једнозначно асоцира на живот по команди, или пак на живот под командом, живот у коме је свако слободно дјеловање готово искључено.

Пјесма се завршава структурно и семантички врло карактеристичним катреном са укршеном римом:

Сувише сам уморан да бих даље пево, ја сам хомо сапиенс, ја сам биће свесно, леви жмигавац кад скрећеш улево, десни жмигавац кад скрећеш удесно....

Правила умарају, готово да убијају, па није никакво чудо да пјесник каже да је сувише уморан да би „даље пево”. Његова изјава да је „хомо сапиенс”, односно „биће свесно” као да је побуна против тортуре правила, али је заправо својеврсни увод у парадокс који настаје навођењем „потврде” у два посљедња стиха завршне строфе, односно пјесме у цјелини. Пјесник, наиме, као потврду за то да је „биће свјесно” наводи вршење радње која не захтијева никакву свјесну активност, него представљају готово аутоматизоване, спонтане покрете: леви жмигаваи, кад скрећеш улево, / десни жмигаваи, кад скерећеш удесно. Семантички се та два стиха супротстављају првим двама стиховима прије свега по типу субјекта. У првим двама стиховима субјекат је лични, везан за прво лице, препознатљиво или по личној замјеници (ја) или по форми личног глаголског облика (бuх пево; ја сам..). У посљедњим двама стиховима субјекат није лични, него уопштенолични изражен презентском формом другог лица (скрећеш). „Хомо сапиенс” као свјесно биће добија „идентитетску” потврду у општем, механичком, готово бизарном правилу о укључењ улијевог или десног жми- 
гавца за скретање удесно или улијево. А то „аутоматизовано" правило исказано је двама стиховима прожетим цијелим низом еквивалентности. Тако та два стиха повезује тролексичка мезофора (жмигаваи, кад скрећеш), али и антонимност почетних и завршних лексема, придјева и прилога (леви-десни; улево-удесно), с тим да су те придјевске и прилошке антонимске лексеме у парагменонском стилском односу, ${ }^{10}$ будући да их повезује исти коријен (лев, односно десн).

Завршетак пјесме је баш као и њен почетак презасићен типовима еквивалентности, али неподудараним, што на најбољи начин показује садејство римованих и неримованих еквивалентних јединица у творби пјесничке функције језика, као недвосмисленог показатеља језичко-поетске вриједности саме пјесме. Јер, еквивалентност звука свој пандан добија у семантичкој еквивалентности.

\section{3. Закључак}

Проведена анализа риме на основу примјера из четири збирке поезије Боре Ђорђевића, и то првих трију штампаних (Равнодушан према плачу, Хеј Словени, и Првих десет година је најтеже) и посљедње објављене Ђорђевићеве збирке (Пусто острво), показала је да је рима најсуштаственија карактеристика поезије Боре Ђорђевића. Томе је најбољи показатељ чињеница да су од свих пјесама у четирима анализираним збиркама Борине поезије само двије неримоване, као и то да су код Боре Ђорђевића заступљени готово сви родни,

10 «Парегменон подразумијева реализацију двију или више лексема једне творбене породице. тј. лексема обједињених истим коријенским морфемом» (Ковачевић 1998:146). 
квалитативни и дистрибуциони типови рима. Еуфонијска и поетска фунција риме у Ђорђевићевој поезији су у двоструко импликативном односу, готово да једна другу подразумијевају, и надопуњавају. Осим тих двију фунцкија, у поезији Боре Ђорђевића рима има и текстуалну кохезивну и кохеренцијску улогу. Зато рима и јесте стилско-језичка доминанта цијеле Ђорђевићеве поезије. „Попут улоге, које су имале у поетици симболизма - стављене у метричке оквире - речи могу да остваре не само звучно сагласје, већ и да постакну семантичку луцидност", али се, баш као у хип-хопу, и у перцепцији пјесама Боре Ђорђевића, неоправдано „често догађа да сазнајна вредност текста буде занемарена у корист 'декоративне', која се огледа у рими” (Ђорђевић 2016:75-76).

\section{Корпус}

Ђорђевић 1986: Bora Đorđević, Ravnodušan prema plaču, Beograd: Književne novine, 1986.

Ђорђевић 1987: Bora Đorđević, Hej Sloveni, II izdanje, Beograd: Bora Đorđević, Slobodan Lovrić, 1987.

Ђорђевић 1988: Bora Đorđević, Prvih deset godina je najteže: sve pesme „Riblje čorbe” i malo više, Beograd: Bora Đorđević, Dušan Dedić, Miroslav Dereta, 1988.

Ђорђевић 2017: Бора Ђорђевић, Пусто острво, Београд: Арте, 2017.

\section{Литература}

Грдинић 2007: Никола Грдинић, Стални облици песме и строфе, Београд: Народна књига, 2007.

Ђорђевић 2016: Dragan M. Đorđević, „Krugovi buksne” kao metod: ekspertiza rimovanja u hip-hop kulturi, Српски језик, књижевност, уметност, кю. 2: Rock'n'roll, Крагујевац: ФИЛУМ, 2016, 73-80. 
Јакобсон 1966: Roman Jakobson, Lingvistika i poetika, Beograd: Nolit, 1966.

Јакобсон 1978: Roman Jakobson, Dominanta, Ogledi iz poetike, Beograd: Prosveta, 1978, 120-126.

Ковачевић 1998: Милош Ковачевић, Стилске фигуре и кюижевни текст, Београд: Требник, 1998.

Маројевић 2000: Радмило Маројевић, „Реченице са уопштеноличним значењем у руском језику у поређењу са српским”, Српски језик данас, Београд: ЗИПС, Српска радикална странка, 2000, 234-247.

Ружић 2008: Žarko Ružić, Enciklopedijski rečnik versifikacije, Sremski Karlovci-Novi Sad: Izdavačka knjižarnica Zorana Stojanovića, 2008.

Чаркић 2001: Милосав Ж. Чаркић, Појмовник риме, Београд: Институт за српски језик САНУ, Бањалука: Филозофски факултет, 2001.

\section{Miloš Kovačević}

\section{RHYMING AS THE STYLISTIC DOMINANT OF BORA ĐORĐEVIĆ'S POETRY}

The paper contains the analysis of the rhyming in the verses coming from the four collections of Bora Đorđevićs poetry comprising the first three printed (Ignorant towards Crying, Hey, Slavs!, The First Ten Years are the Hardest Ones) and the last recently published under the title Desert Island. The rhyming is analyzed with reference to its literary and artistic aspect primarily concerning its role in the creation of poetic function of Đordevićs poems. The rhyming is the most powerful aspect of Bora Đorđevićs poetry which is substantiated by the fact that of all of his poems contained in the four analyzed collections only the two are unrhymed. Besides, the poems offer almost all the types of rhyming considering their gender, qualitative and distributional aspects. The euphonic and the 
poetic function of Đorđevićs rhyming are correlated which means that they are mutually supportive. Apart from the two aforementioned functions the rhyming in the poetry of Bora Đorđevic has textually cohesive and coherence creating role putting it to the pedestal of the basic stylistic dominant not only of the poetry but also of the music that Đorđević creates.

Key words: Bora Đorđević, rhyming, poetry, music, rhythm, euphony, poetic function, gender, quality and the distribution of rhyming 